\title{
Silver Sulfadiazine
}

National Cancer Institute

\section{Source}

National Cancer Institute. Silver Sulfadiazine. NCI Thesaurus. Code C66567.

A sulfonamide-based topical agent with antibacterial and antifung al activity. Silver sulfadiazine may act through a combination of the activity of silver and sulfadiazine. When this agent interacts with sodium chloride-containing body fluids, silver ions are released slowly and sustainably into wounded areas. Ionized silver atoms catalyze the formation of disulfide bonds leading to protein structural changes and inactivating thiolcontaining enzymes; silver ions may also intercalate DNA thereby interfering with replication and transcription of bacteria. As a competitive inhibitor of para-aminobenzoic acid (PABA), sulfadiazine inhibits bacterial dihydropteroate synthase, thereby resulting in disruption of folic acid metabolism and ultimately DNA synthesis. 